\title{
CHEMICAL AND PHARMACOLOGICAL INVESTIGATION OF SOLANUM SPECIES OF BRAZIL - A SEARCH FOR SOLASODINE AND OTHER POTENTIALLY USEFUL THERAPEUTIC AGENTS
}

\author{
J. M. BARBOSA.FILHO; M. F. AGRA; R. A. G. OLIVEIRA; M. Q. PAULO; G. TROLIN; \\ E. V. L. CUNHA; J. R. ATAIDE \& J. BHATTACHARYYA*
}

Laboratório de Tecnologia Farmacêutica, Universidade Federal da Paraíba, Caixa Postal 5009, 58059 , João Pessoa, PB, Brasil *Department of Chemistry, Southeastern Massachusetts University, N. Dartmouth, MA 02747, USA

$A$ systematic search for solasodine, an important starting material for the partial synthesis of steroidal hormones as well as other potentially bioactive constituents of various Solanum species of Brazil has been undertaken. Thus, the fruits of S. paludosum, S. asperum, S. sessiliflorum and Solanum sp. were found to contain significant amounts of solasodine. The root bark of S. paludosum which showed curare like activity yielded tomatidenol and another yet unidentified alkaloid responsible for the biological activity. The fruits of $\mathrm{S}$. asperum yielded a new spirosolane alkaloid, solaparnaine. The stem bark of S. pseudo-quina showed convulsive and excitatory activity from which (25S)-isosolafloridine was identified as the active principle. In addition, the latter alkaloid was also found to show antimicrobial activity.

Key words: solasodine - steroidal hormones - Solanum - alkaloid

The genus Solanum is well known for the presence of $\mathrm{C}_{2}$;-steroidal alkaloids of cholestane skeleton of which the spirosolane, solasodine (1) is most well known and commonly distributed. Most of these alkaloids occur as glycosides in the plant which, upon acid hydrolysis yield the alkamines. Because of the increasing demand for steroidal raw materials, particularly, diosgenin (2), the most important starting material for the production of steroid hormones, there is a worldwide search for an alternative. Soalsodine (1), which was also successfully converted (Sato et al., 1960) to 3ß-acetoxypregna-5,16-dien-20-one (3), has been considered as an alternative to diosgenin. Solasodine was well recognized as the 'diosgenin' of the future. We have been actively searching for a commercially viable source of solasodine in the various Solanum species of northeastern Brazil, in particular. In addition to solasodine in the fruits of several species of Solanum, we encountered other spirosolane alkaloids. Also, the root bark and the stem bark of other Solanum species showed biological activity and the compounds responsible for bioactivity were isolated and characterized. The result of these investigations is summarized in this communication.

Financial support from CNPq, FINEP and CAPES.

\section{RESULTS AND DISCUSSION}

Detection and isolation of solasodine - The fruits of several species of Solanum collected in and around João Pessoa in the State of Paraiba were investigated for the presence of solasodine. The fruits are normally found to be the main source of solasodine. Therefore, the fruits were subjected to the extraction and isolation procedure given in the literature with usual modifications, where necessary (Bhattacharyya, 1984). The result of our investigation of the various Solanum for the isolation of solasodine is given in the Table.

\section{TABLE}

Solasodine content in the green berries of Solanum species

\begin{tabular}{llc}
\hline \multicolumn{1}{c}{ Name of the plant } & \multicolumn{1}{c}{ Place of collection } & \% Solasodine \\
\hline S. paludosum Moric. & João Pessoa, Paraíba & 0.75 \\
S. esperum L. C. Rich. & Santa Rita, Paraiba & 0.67 \\
S. caavurane Vell. & João Pessoa, Paraiba & 0 \\
S. capsicoides All. & João Pessoa, Paraiba & 0 \\
Solanum sp. & Teresina, Piauí & 1.10 \\
S. sessiliflorum Dun. & Chapada de Tapequem & \\
& Roraima & 0.30 \\
\hline
\end{tabular}

The green fruits of $S$. paludosum, the most abundant local species, were found to contain the highest amounts of solasodine in addition 
to another alkaloid, referred to here as alkaloid A. The structure of alkaloid A is not yet known. The in vitro culture of this plant as a economically viable source of solasodine is presently being investigated.

Investigation of S. asperum L.C. Rich - The fruits of this plant, commonly known as 'jussara', were found to contain two more alkaloids in addition to solasodine (Table). The alkaloids were characterized (Bhattacharyya, 1985 ) to be 3,5-soladiene (4) and a new alkaloid, solaparnaine (5). As solaparnaine has only a $\mathrm{OH}$ function as $\mathrm{C}-27$ of the piperidine ring, it is also potentially convertible, like solasodine, to useful steroidal compounds.

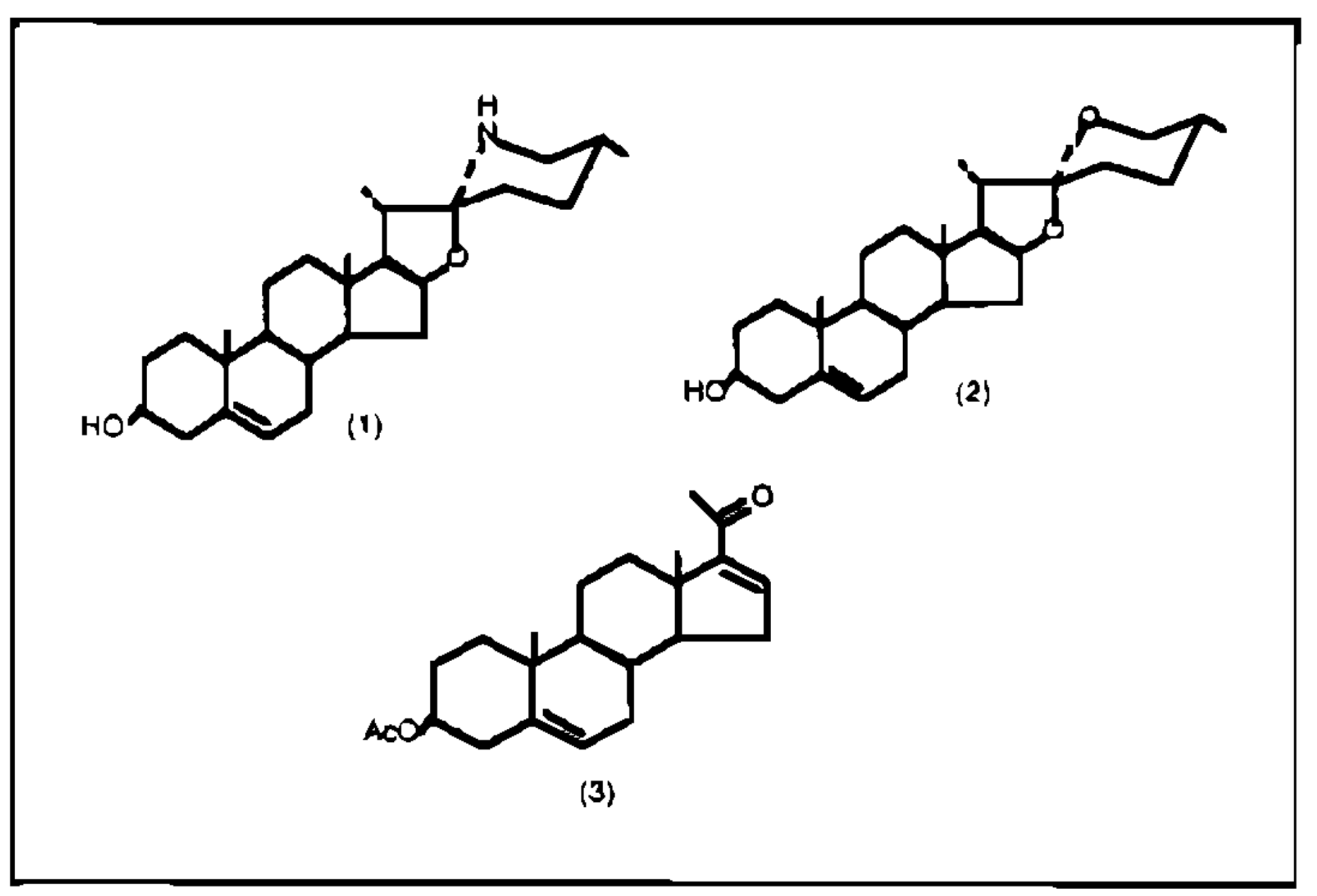

Investigation of the root bark of S. paludosum Moric - $S$. paludosum Moric is native to northeastern Brazil and grows abundantly alongside other species of Solanum having medicinal use. However, there is no mention of the use of this plant in popular medicine. The ethanolic extract of the root bark of this plant showed (Ataide, 1982) significant curare like activity which is competitive and reversible. The extract also showed anti-muscarinic activity in addition to rther minor effects. The curare like activity was found to be concentrated in the crude aikaloidal fraction. A systematic chemical investigation of the crude alkaloids monitored by the physiological activity resulted in the isolation of two alkaloids. One of these compounds, $\mathrm{C}_{2}{ }_{7} \mathrm{H}_{43} \mathrm{NO}_{2}, \mathrm{mp} \quad 238-240{ }^{\circ} \mathrm{C}$, which wis not the active principle, was characterized by ${ }^{13} \mathrm{C}$ NMR spectroscopy as tomatidenol (6). The second alkaloid, referred to here as alkaloid $\mathrm{B}, \mathrm{C}_{2}, \mathrm{H}_{4}{ }_{3} \mathrm{NO}_{3}, \mathrm{mp} 215-218{ }^{\circ} \mathrm{C}$, was found to be the compound responsible for the curare like activity (Brito, 1987). The structure of this alkaloid is presently under investigation.
Investigation of the stem bark of S. pseudoquina St. Hil - S. pseudo-quina is a tree which grows in the state of Paraná in southern Brazil and the stem bark of this plant is traditionally used in that region as tonic and febrifuge. The green fruits of $S$. pseudo-quina was alleged to contain an epiiminocholestane alkaloid, solaquidine (Usubillaga et al., 1977). No further investigation is reported on this plant. The crude ethanolic extract of the stem bark of $S$. pseudo-quina produced excitatory effects dominated by convulsions in rats and mice and this effect was found to be concentrated in the alkaloidal fraction. When subjected to the usual separation techniques monitored by the biological activity, a slightly impure alkaloidal material was found to be responsible for the specific excitatory activity shown by the crude extract (Oliveira et al., 1988). Several recrystallizations did not effectively purify the major constituent which was characterized by ${ }^{13} \mathrm{C}$ NMR spectroscopy to be (25S)-isosolafloridine contaminated by another yet unidentified compound.

In a preliminary investigation, (25S)-isosola. floridine was also found to be the compound responsible for the inhibition of the growth of Candida albicans and Staphylococcus aureus (Lima et al., 1989) demonstrated by the crude ethanolic extract of the stem bark of $S$. pseudoquina. The detailed results of this work will appear elsewhere.

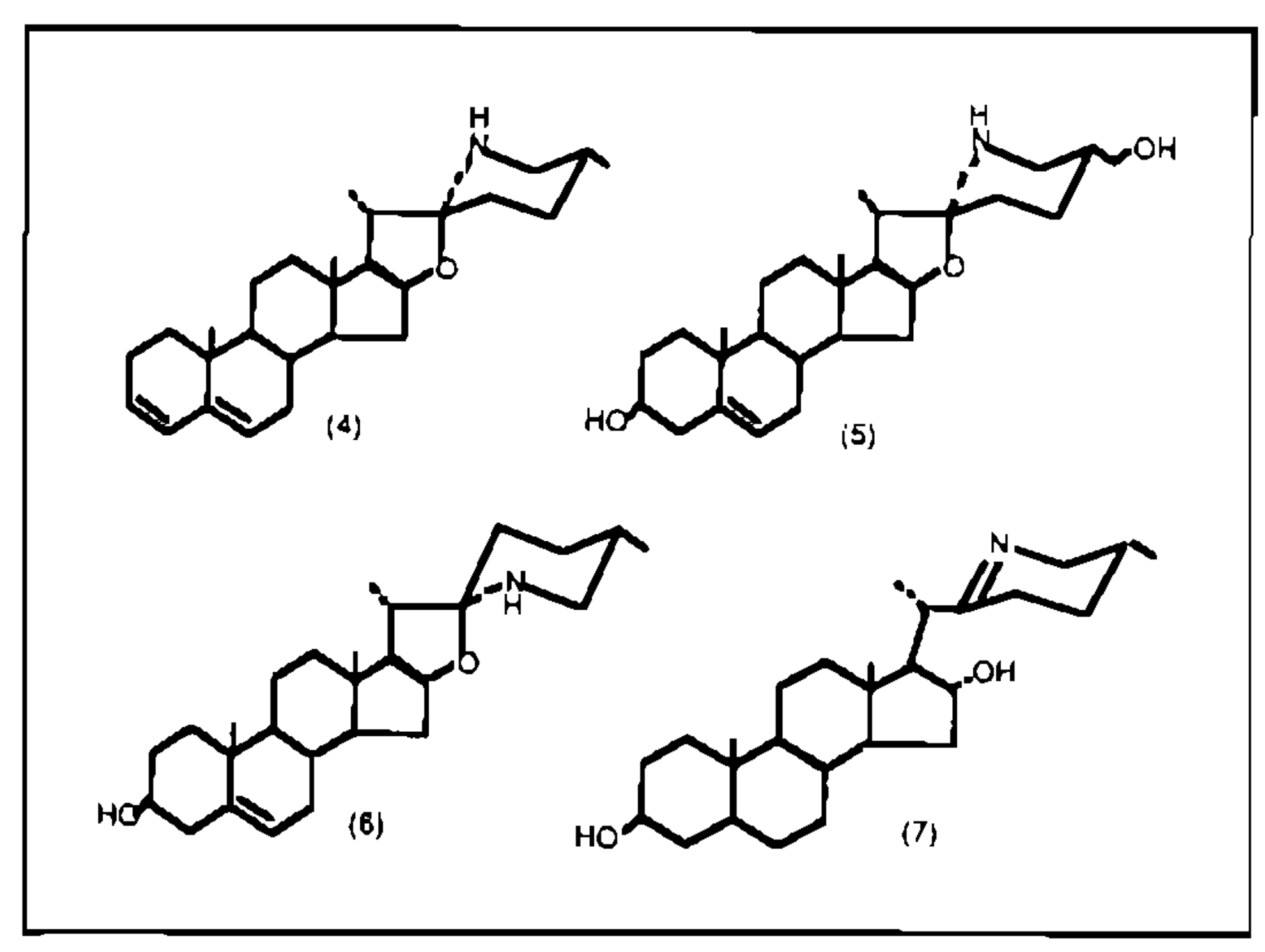

\section{ACKNOWLEDGEMENTS}

To Prof. Delby Fernandes de Medeiros, Director, for his enthusiasm, encouragement and help through the project. To Ms Dulce Gonçalves de Oliveira for technical assistance. 


\section{REFERENCES}

ATAIDE, J. R., 1982. Atividade farmacologica dos extratos da Jurubeba-roxa, a Solanum paludosum Moric., M. S. Thesis, Universidade Federal da Paraíba, Joāo Pessoa, PB, Brazil.

BHATTACHAR YYA, J., 1984. Isolation of solasodine from the fruits of Solanum asperum and $S$. paludosum. J. Nat. Prod., 47: 1059 and references cited therein.

BHATTACHARYYA, J., 1985. Structure of solaparnaine, a new spirosolane alkaloid from the green berries of Solanum asperum Vahl. Heterocycles, 23: 3111-3112.

LIMA, E. O.; MAIA, R. F.; OLIVEIRA, R. A. G.;
PAULO, M. Q. \& BHATTACHARYYA, J., 1990. Isolation of the antimicrobial constituent of the stem bark of $S$. pseudo-quina. Planto Medica. submitted.

OLIVEIRA, R. A. G.; BHATTACHARYYA, J.; CARVALHO, L. A. E.; LEONART, R.; PAULO, M. Q. \& TROLIN, G., 1988. Convulsive action of (25S)-isosolafloridine isolated from Solanum pseudo-quina bark. J. Ethnopharmacol., 24:155-165.

SATO, Y.; IKEKAWA, N. \& MOSSETIG, E., 1960. J. Org. Chem., 25:783-786.

USUBILlAGA, A.; CASTELLANO, G.; HIDALGO, J.; GUEVARA, C.; MARTINOD, P. \& PAREDES, A., 1977. Solaquidine, a new steroidal alkaloid from Solanum pseudo-quina. Phytochemistry, 16: 1861-1862. 